\title{
ANALYSIS OF THE POSSIBILITY OF PARALLEL IMPLEMENTATION OF THE QUALITY MANAGEMENT SYSTEM AND OF THE CORPORATE SOCIAL RESPONSIBILITY SYSTEM INTO A NEW ORGANIZATION
}

doi: 10.2478/cqpi-2019-0027

Date of submission of the article to the Editor: 15/03/2019

Date of acceptance of the article by the Editor: 09/05/2019

Zdenka Hofbruckerová ${ }^{1}$ - orcid id: 0000-0002-4451-4578

Martin Václavík ${ }^{1}$

1VSB-TU Ostrava, Department of quality management, 17. listopadu 2172/15 Czech Republic

Abstract: Corporate Social Responsibility (CSR) concept is focused on understanding and managing the impacts a company has on the world around it and doing so as a part of core business activities. The common practice of most organizations is to implement a quality management system (mostly according to ISO 9001), and then implement other management systems. Companies in the Czech Republic have the possibility of certification of CSR via the Czech standard CSN 01 0391: 2013 which corresponds to the structure and requirements of other ISO standards. The article analyses common elements of both standards. The output is a proposal of the process of parallel implementation of these two management systems into a newly established organization.

Keywords: Corporate Social Responsibility, Quality Management System, ISO standard, certification

\section{INTRODUCTION}

In the current turbulent times, it is very important for a newly established company to ensure the competitiveness of its products or services at the beginning of its existence. One such way may be, for example, the implementation of some management systems - quality, environment, occupational health and safety - that are referred to as integrated management systems as a whole. Organizations that already have an integrated management system in place will then continue to look at other development opportunities. If they decide again for management systems certification, they focus on social responsibility, information security, energy management, etc.

However, the usual practice of emerging firms is that the owners first ensure production and only then start to improve in the form of management systems certification. At the same time, the introduction of the system into a newly established company is neither too time-consuming nor financially burdensome. For new firms, it is beneficial to start building management systems in parallel with designing production processes. 


\subsection{Quality Management System}

ISO 9001:2015 is an international standard for Quality Management System (QMS) implementing. QMS is a set of rules focused on meeting consumer requirements and enhancing his/her satisfaction. Similarly like organizational Excellence (EFQM Mdel), Environmental Management System (according to ISO 14001:2015), OH\&S management system (ISO 45001:2018) and others provides a competitive advantage it is what makes one organization different from all of the other organizations in certain marketplace that provide similar products or services (Nenadál, Vykydal and Waloszek, 2018). It is stated as the combination of organizational goals, aspirations, processes, documented information and resources needed to implement and maintain production (services) according to customer requirements. Quality management systems from its beginning emphasized predictable outcomes of an industrial product production line, using simple statistics and random sampling. In modern approach, QMS has tended to converge with sustainability and transparency initiatives, as both investor and customer satisfaction and perceived quality is increasingly tied to these factors. Using Annex SL in the process of revision of ISO standards brings the opportunity to implement more management systems to an organization in a parallel way and to increase competitiveness of the business.

\subsection{Corporate Social Responsibility}

Social responsibility is the responsibility of an organization for the impacts of its decisions and activities on society and the environment, through transparent and ethical behaviour (European Commission, 2011). The concept of corporate social responsibility is based on three pillars: economic, environmental and social. From the 1970s, stakeholders conception has also been a part of CSR (Freeman, 2010). But the role of the stakeholder approach is also a part of the newest edition of ISO 9001 standard (ISO 9001:2015).

In Czech conditions, the national standard for CSR was issued in 2013 according to Annex SL too. The ČSN 01 0391:2013 is a Czech national standard which specifies requirements for the management system of social responsibility. The standard tries to offer the way how to integrate CSR management system requirements for the individual pillars (economic, environmental and social) and requirements for improvement following the PDCA cycle. The standard can be used for certification on the national level.

This standard is most suitable for organizations that have already implemented some management system (according to ISO 9001, 14001, OHSAS), under various chapters of these international standards. Appropriate chapters and the similar structure can help organizations to transform requirements of CSR according to ČSN 010391 to the existing integrated management system more easily (Markulík and Kamenický, 2015). There are also many opportunities of funding through European sources to implement the CSR management system (Košt'álová and Tetřevová, 2017). Although the CSR concept is well known widely, it is a pity that many organizations that carry out many CSR activities do not use it as a potential competitive advantage. As earlier research has shown, the organizations claiming the concept of corporate social responsibility do not meet the requirements of all three pillars in mutual balance (Hofbruckerová et al., 2018). The article analyses common elements of both standards. The output is a 
proposal of the process of parallel implementation of these two management systems into a newly established organization.

\section{METHODOLOGY}

The methodology applied in this paper is the comparison of contents of two management systems standards: ISO 9001:2015 - Quality Management Systems Requirements and ČSN 01 0391:2013 Corporate Social Responsibility Management Systems - Requirements. The aim is to find out which requirements both standards have in common. If it is more than half of the monitored requirements, it is possible to recommend the joint implementation when establishing a new company. This process will save resources, increase competitiveness, and improve organization image with stakeholders.

\section{RESULTS}

ISO 9001 standard has 10 chapters, and ČSN 010391 has 12 chapters. Chapters 1, 2, 3 of ČSN 010391 relate to general principles such as the subject matter, documents cited, terms and definitions. Therefore, these chapters do not need to be addressed.

Table 1 shows the common requirements of both standards on the management systems. There are requirements of CSR standard in the first column and parallel requirements of ISO 9001 standard in the second column. The third part of the table shows the differences. Chapters written there are almost completed from the view of both analysed standards but there are few small revisions needed. For example there is in the chapter 5 requirement to add to quality policy statement also the principles of CSR policy. Chapters 9 and 10 of QMS is even more detailed than requirements for CSR are.

The chapters of CSR standard that are not included in ISO 9001 and the organization will have to prepare them from the beginning are the ones focused on CSR specific areas:

Chapter 6 Stakeholders

Chapter 7 Economic Responsibility Aspects in the Economic Area

Chapter 8 Environmental Responsibility Aspects

Chapter 9 Social responsibility aspects in the social field

Chapter 10 Resource Management

In contrast to the Czech standard ČSN 01 0391, the new terminology, such as documented information, is used in ČSN EN ISO 9001: 2016, the interested parties, which are explained in the previous chapters and the CSR standard are still in the old version.

Table 1

Comparison of common requirements of ISO 9001 and ČSN 010391

\begin{tabular}{|c|c|c|}
\hline $\begin{array}{c}\text { ČSN 01 0391:2013 } \\
\text { Chapter }\end{array}$ & $\begin{array}{c}\text { ISO 9001:2015 } \\
\text { Chapter }\end{array}$ & To add \\
\hline 5 LEADERSHIP & 5 LEADERSHIP & $\begin{array}{c}\text { Integration of CSR } \\
\text { requirements into enterprise } \\
\text { business processes }\end{array}$ \\
\hline
\end{tabular}




\begin{tabular}{|c|c|c|}
\hline $\begin{array}{l}\text { 5.2 POLICY OF SOCIAL } \\
\text { RESPONSIBILITY }\end{array}$ & 5.2 POLICY & $\begin{array}{l}\text { 1) Define a framework for } \\
\text { setting goals } \\
\text { 2) to supplement the CSR } \\
\text { commitment }\end{array}$ \\
\hline 5.3.1 OBJECTIVES & $\begin{array}{c}\text { 6.2 QUALITY OBJECTIVES } \\
\text { AND PLANNING TO } \\
\text { ACHIEVE THEM }\end{array}$ & $\begin{array}{l}\text { 1) define steps to achieve the } \\
\text { goals set } \\
\text { 2) provide resources } \\
\text { 3) designate a responsible } \\
\text { person } \\
\text { 4) when goals will be } \\
\text { achieved and their evaluation }\end{array}$ \\
\hline 11 COMMUNICATION & 7.4 COMMUNICATION & The chapters are identical \\
\hline $\begin{array}{l}\text { 4.2; 4.2.2 DOCUMENTATION } \\
\text { REQUIREMENTS; } \\
\text { CONTROL OF DOCUMENTS } \\
\text { AND RECORDS }\end{array}$ & $\begin{array}{l}\text { 7.5 DOCUMENTED } \\
\text { INFORMATION }\end{array}$ & The chapters are identical \\
\hline $\begin{array}{l}\text { 12. MEASUREMENTS, } \\
\text { ANALYSIS AND } \\
\text { IMPROVEMENT }\end{array}$ & $\begin{array}{l}\text { 9. PERFORMANCE } \\
\text { EVALUATION }\end{array}$ & $\begin{array}{l}\text { Chapter } 9 \text { is more detailed } \\
\text { than required for CSR }\end{array}$ \\
\hline 12.2 INTERNAL AUDITS & 9.2 INTERNAL AUDITS & $\begin{array}{c}\text { Chapter } 9.2 \text { is more detailed } \\
\text { than required for CSR }\end{array}$ \\
\hline 12.3 REVIEW & 9.3 MANAGEMENT REVIEW & $\begin{array}{c}\text { Chapter } 9.3 \text { is more detailed } \\
\text { than required for CSR }\end{array}$ \\
\hline $\begin{array}{c}\text { 12.4; } 12.4 .1 \text { IMPROVEMENT; } \\
\text { CONTINUAL } \\
\text { IMPROVEMENT }\end{array}$ & $\begin{array}{c}\text { 10; } 10.3 \text { IMPROVEMENT; } \\
\text { CONTINUAL } \\
\text { IMPROVEMENT }\end{array}$ & $\begin{array}{l}\text { Chapters } 10 \text { and } 10.3 \text { are } \\
\text { more detailed than required } \\
\text { for CSR }\end{array}$ \\
\hline $\begin{array}{l}\text { 12.4.2 CORRECTIVE } \\
\text { ACTION }\end{array}$ & $\begin{array}{l}\text { 10.2 NONCONFORMITY } \\
\text { AND CORRECTIVE ACTION }\end{array}$ & $\begin{array}{l}\text { 1) Plan and implement } \\
\text { preventive measures } \\
\text { 2) record their results } \\
\text { 3) verify the effectiveness of } \\
\text { the implemented measures }\end{array}$ \\
\hline
\end{tabular}

Source: (own source)

\section{CONCLUSION}

The analysis showed that the parallel implementation of both standards ISO 9001 and ČSN 010391 into an emerging business is easier than leaders often think. Time and administrative complexity are often cited as a basic barrier to CSR implementation (Hofbruckerová and Divinová, 2016). However, this analysis confirmed that many requirements of both standards are identical or there are only minor differences between them. The basic difference is just the basic focus of CSR standards - three pillars of CSR and stakeholder approach. It should be great advantage of new establishing business to implement both standards in a parallel way in the beginning of its existence. It could save resources and, at the same time, increase image and stakeholders' loyalty, customers' interest and satisfaction of employees, business partners, etc.

\section{ACKNOWLEDGEMENTS}

This paper was elaborated in the frame of the specific research projects No. SP 2019/129, which has been solved at the Faculty of Metallurgy and Materials Engineering, VŠB-TU Ostrava with the support of Ministry of Education, Youth and Sports, Czech Republic. 


\section{REFERENCES}

ČSN 01 0391:2013 Corporate social responsibility management system Requirements

European commission, 2011. Communication from the Commission to the European Parliament, the Council, the European Economic and Social Committee and the Committee of the Regions. Brusel: European Commission.

Freeman, R. E., 2010.Strategic Management: A Stakeholder Approach, Cambridge University Press, New York, USA.

Hofbruckerova Z., Divinová, T., 2016. Corporate Social Responsibility in Czech Enterprises. I kongres młodych ekonomistów w PTE dla gospodarki Polski: Współczesne problemy ekonomii - między teorią a praktyką gospodarczą, Polskie Towarzystwo Ekonomiczne, Czestochowa, Poland.

Hofbruckerová, Z., Halfarová, P., Uherková, A., 2018. Level of compliance with the requirements of corporate social responsibility in Czech enterprises, $12^{\text {th }}$ International Conference Quality Production Improvement, QPI 2018, Zaborze near Myszkow, Poland

ISO 9001:2015, Quality management Systems - Requirements

Koštálová, J., Tetřevová, L., 2017. Supporting CSR activities of metallurgical companies in the Czech Republic from EU sources, $26^{\text {th }}$ International Conference on Metallurgy and Materials, Ostrava, Tanger, 2200-2205.

Markulík, Š., Kamenický, L., 2015. How to transform the requirements into the management system?, SGEM, Sofia, 689-693.

Nenadál J., Vykydal D., Waloszek D., 2018. Organizational Excellence: Approaches mOdels and Their Use at Czech Organizations, Quality Innovation Prosperity 22(2), 47-64, DOI: 10.12776/QIP.V22I2.1129 